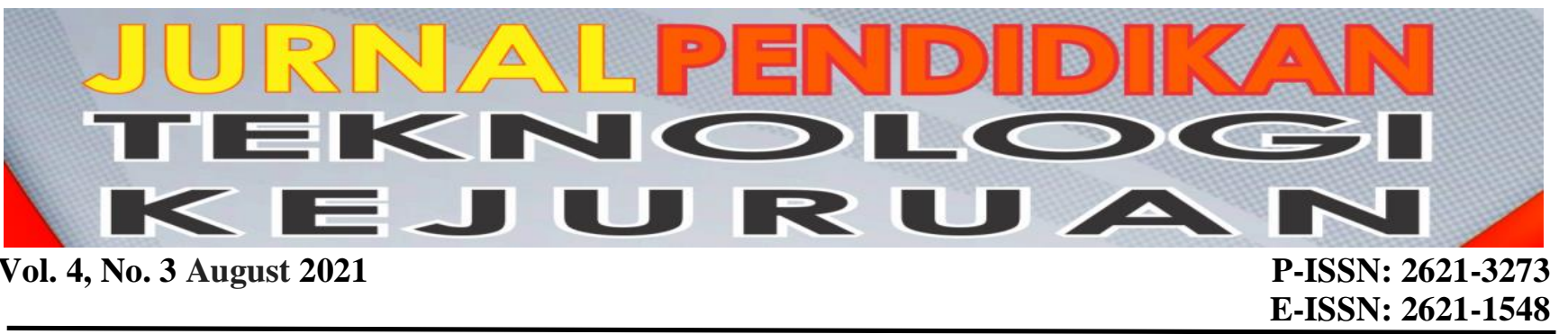

\title{
The Effect of Customer Experience on Repurchase Intention with Variety Seeking as Variable Moderation at 4-Star Hotels
}

\author{
Youmil Abrian', Arif Adrian² \\ ${ }^{1,2}$ Tourism Department, Faculty of Tourism and Hospitality, Universitas Negeri Padang \\ *Corresponding author, e-mail: abrian.yomil@fpp.unp.ac.id
}

\begin{abstract}
This research aims to determine the influence of customer experience on repurchase intention with variable moderation of variety seeking. The form of statistical analysis used is moderated analysis regression. The selection of 4-star hotels due to the standard of star hotels pays attention to the increasingly varied needs of consumers. The target population in this study was hotel guests who had stayed at a 4-star hotel in Padang. A simple random sampling technique is used. with 286 samples. In obtaining the data used a questionnaire with a Likert scale. From the results of the study obtained the influence of variable customer experience had a significant positive effect on the repurchase intention, with a significance value of $0,000<0.05$ and had an influence contribution of $4.5 \%$, with a regression coefficient of 0.125 . While variety-seeking variables have a significant negative effect on repurchase intention with a significance value of $0<0.05$, and have an influence contribution of $6 \%$, with a regression coefficient of $\mathbf{- 0 . 1 9 7}$. From the results of moderation regression obtained variety seeking to moderate the influence of customer experience on repurchase intention negatively with the significance of $0,000<0.05$, and has a regression coefficient of -0.537 with an influence contribution of $8.7 \%$.
\end{abstract}

Keywords: Customers Experience, Variety Seeking, Repurchase Intention

\section{INTRODUCTION}

The West Sumatra tourism industry is currently experiencing good development, starting from 2015 to 2018 , the revenue generated from the tourism sector has increased to 405 percent, while the number of visits has increased by 30 percent during 2019, the city of Padang as the provincial capital has become the center of government attention improve the tourism sector. After being crowned, the city of Padang became a potential city for the Indonesian Attractiveness Award in the 2018 tourism category (Hendra, 2019)

The development of the tourism industry is synonymous with the increasing number of hotels available. Based on the latest data obtained from the culture and tourism office of the city of Padang, 111 lodgings have been officially registered. Among them, there are 64 -star hotels in the city of Padang "The high level of tourist visits is in line with the high occupancy rate of hotel rooms in the city of Padang" (Riyon, 2019)
Table 1.

Occupancy and frequency of repeat order customer

\begin{tabular}{rccccccccc}
\hline Hotel & $\begin{array}{c}\text { Roo } \\
\text { m }\end{array}$ & \multicolumn{2}{c}{ Sept } & \multicolumn{2}{c}{ Oct } & \multicolumn{2}{c}{ Nov } & \multicolumn{2}{c}{ Dec } \\
\hline $\begin{array}{r}\text { Rocky } \\
\text { Plaza }\end{array}$ & 164 & 86 & 2,82 & 91,2 & 3,1 & 90,2 & 3,6 & 73,7 & 3,2 \\
$\begin{array}{r}\text { Pangeran } \\
\text { Beach }\end{array}$ & 146 & 85 & 8,2 & 89,9 & 8,8 & 91,0 & 9,6 & 82,1 & 9,3 \\
$\begin{array}{r}\text { The } \\
\text { Axana }\end{array}$ & 178 & 70, & 3,2 & 87 & 2,9 & 90,8 & 4.5 & 82,6 & 2,7 \\
Mercure & 141 & 90 & 3,3 & 93 & 2,8 & 94,6 & 2,7 & 87,0 & 2,9 \\
$\begin{array}{r}\text { Kyriad } \\
\text { Bumimin }\end{array}$ & 102 & 92 & 1,8 & 97,1 & 2,1 & 96,5 & 2,3 & 96 & 2,3 \\
ang & & & & & & & & & \\
Grand & 168 & 83 & 2,2 & 86,3 & 1,9 & 90.4 & 2,84 & 80,95 & 2,2
\end{tabular}

Based on the data, it can be seen that the high level of hotel occupancy, but the high occupancy rate of this hotel is not followed by repeat orders or hotel room purchases, which have a low percentage. Where less than $10 \%$ of the rate of re-purchase of rooms by guests at 4-star hotels in the city of Padang. Repurchase intention is a consumer commitment that is formed after a consumer purchases a product or service (Hicks et al., 2005). Repurchase intention can 
be influenced by many factors including the quality of the product or service and the experience obtained after using the product or service (Bianca, 2011)

Consumer behavior in the future is influenced by consumer satisfaction and dissatisfaction after purchasing a product (Kotler, Philip \& Keller, n.d.). If the consumer is satisfied, the consumer can buy the product back. If the product meets expectations, consumers may buyback, but if the product disappoints, consumers will look for better alternatives). If consumers are not satisfied or have a bad experience, consumers will look for alternative products or services that provide different variations of offerings (Sang et al., 2018).

The Customer experience will be fulfilled if there is an interaction with the services provided (Alnawas \& Hemsley-Brown, 2019). The impact of the consumer's experience is of course directly proportional to the experience obtained by the consumer as cited in (Kandampully et al., 2018),. The concept of customer service experience and experience is a unity because formulating the right scale for evaluating service experience remains to be seen from the perspective of the customer (Klaus, $\mathrm{Ph}$. and Maklan, 2011). The customer experience is very important for the company to manage. The process of managing customer experience becomes an important strategic ingredient for service companies as cited in (Jorge Teixeira, Lia Patrício, Nuno J. Nunes, Leonel Nóbrega, Raymond P. Fisk, 2012). The opinion of Klaus was also shared by Teixeira, et al. where customer experience can be a source of sustainable competitive advantage in the company (Jorge Teixeira, Lia Patrício, Nuno J. Nunes, Leonel Nóbrega, Raymond P. Fisk, 2012). 4-star hotels have criteria that can provide direct or indirect experience, standards or criteria for establishing 4-star hotels are based on the level of fulfillment of increasingly complex consumer needs, in the sense that consumers have many alternatives or variations (variety seeking) or choices for room needs a given hotel raises an intention to repurchase hotel rooms in the future.

Variety seeking is a purchase that is looking for variations, namely purchases made when consumers make purchases spontaneously and aim to try new brands of a product, in this case, consumers often change brands to look for diversity (Kotler, Philip \& Keller, n.d.). This behavior variety-seeking tends to occur when purchasing a product that poses minimal risk to consumers and when consumers are less committed to something, (Sharma, Piyush, Bharadhwaj Sivakumaran, 2009).
Based on the description above is expected to provide information on how much the influence of customer experience moderated by the variety-seeking variable on repurchase intention at 4-star hotels in the city of Padang. In general, the objective of the research is to determine the effect of customer experience on repurchase intention and to determine the effect of variety seeking on repurchase intention, and to find out how much influence the variable variety Seeking has moderated the effect of customer experience on repurchase intention of guests at 4-star hotels in the city of Padang.

\section{METHOD}

Based on the problems and objectives to be achieved, this type of research is classified as causal associative research. The population in this study are consumers who have stayed at a 4-star hotel in Padang. The determination of the number of samples used by the author in this study is based on the Slovin method as a measuring tool for calculating the sample size and obtaining a sample of 286 samples. The instrument for collecting data in this study was a questionnaire prepared using a Likert scale with 5 answer choices. Before the questionnaire is used, first the validity and reliability tests are carried out. This is to determine the limits of truth and accuracy of measuring instruments for an indicator of research variables. Furthermore, the classical assumption test is carried out, namely the multicollinearity test, autocorrelation test, and heteroscedasticity test.

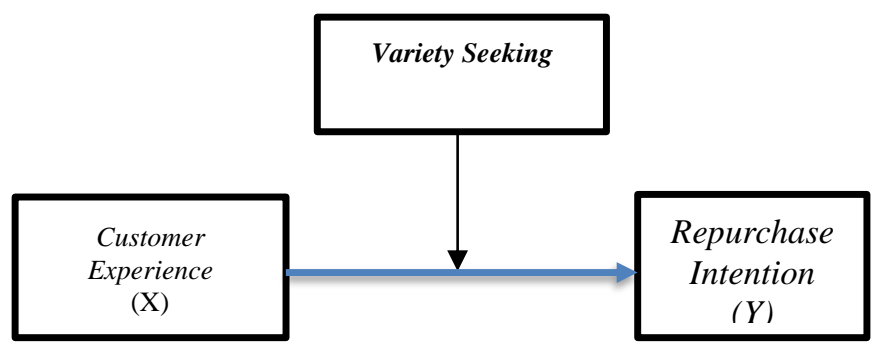

Figure 1. Hypothesis Framework

The analysis technique uses the moderated regression analysis (MRA) method which can be calculated using the formula:

$\mathrm{Y}=\mathrm{a}+\mathrm{b} 1 \mathrm{X} 1+\mathrm{b} 2 \mathrm{X} 2+\mathrm{b} 3 \mathrm{X} 1 \mathrm{X} 2+\varepsilon$

$\mathrm{Y}=$ predicted value

$\mathrm{a}=$ constant

$\mathrm{b} 1=$ regression coefficient for $\mathrm{X} 1$

$\mathrm{b} 2=$ regression coefficient for $\mathrm{X} 2$

b3 $=$ moderating variable coefficient 


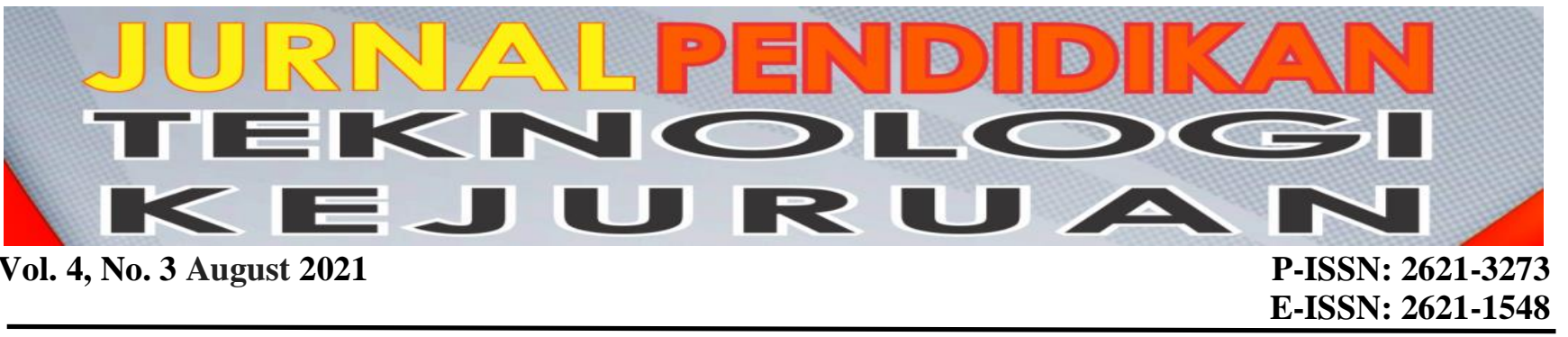

\section{RESULT}

The first hypothesis test in this study is to see the effect of Customer Experience on Repurchase Intention in 4-star hotels in Padang City.

The score of $\mathrm{R}$-value of 0.213 indicates that the correlation or relationship between the dependent variable and the independent variable has a strong enough relationship. From the table above, it is also known that the value of $\mathrm{R}$ Square to see the contribution of the influence of Customer Experience on Repurchase Intention is 0.045. This means that the contribution of the influence of the independent variable on the dependent variable is $4.5 \%$, while the remaining $95.5 \%$ is influenced by other variables not examined in this study

\section{Hypothesis test (H2)}

The second hypothesis test in this study is to see the effect of Customer Experience on Repurchase Intention with the Seeking variety as a Moderation variable at 4-star hotels in Padang City.

From the moderation regression analysis, it can be seen that the Seeking variety can moderate the effect of Customer Experience on Repurchase Intention. This can be proven from the calculated $F$ value of 8.9 with a significance value of 0.00 less than 0.05 .

\section{Test of Moderation Regression Coefficient}

The results of the regression coefficient analysis of the influence of Customer Experience on Repurchase Intention can be seen in the following table:

\begin{tabular}{|c|c|c|c|c|c|}
\hline \multicolumn{6}{|c|}{ Coefficients $^{\mathrm{a}}$} \\
\hline \multirow[b]{2}{*}{ Model } & \multicolumn{2}{|c|}{$\begin{array}{l}\text { Unstandardized } \\
\text { Coefficients }\end{array}$} & \multirow{2}{*}{\begin{tabular}{|c}
$\begin{array}{c}\text { Standardized } \\
\text { Coefficients }\end{array}$ \\
Beta
\end{tabular}} & \multirow[b]{2}{*}{$\mathrm{t}$} & \multirow[b]{2}{*}{ Sig. } \\
\hline & B & Std. Error & & & \\
\hline 1 (Constant) & 56.996 & 2.956 & & 19.281 & .000 \\
\hline$(\mathrm{CE})$ & 5.317 & 1.988 & .972 & 2.675 & .008 \\
\hline (VS) & -2.346 & 1.435 & -.429 & -1.635 & .103 \\
\hline X3mdrasi & -.537 & .222 & -.736 & -2.418 & .016 \\
\hline
\end{tabular}

From the results of the Moderation regression analysis above, it can be seen that the Seeking variety can moderate the effect of Customer Experience on Repurchase Intention, with a significance of 0.000 $<0.05$.

With the regression equation, the results of statistical calculations are as follows:

$$
\begin{aligned}
& \mathrm{Y}=\mathrm{a}+\mathrm{b} 1 \mathrm{X} 1+\mathrm{b} 2 \mathrm{X} 2+\mathrm{b} 3 \mathrm{X} 3 \\
& \mathrm{Y}=56.996+5.317 \mathrm{X} 1-2.346 \mathrm{X} 2-0.537 \mathrm{X} 3
\end{aligned}
$$

From the above equation, the Customer Experience variable has a regression coefficient of 5,317 with a significant value of $0.00<0.05$, so Customer Experience has a significant positive effect on Repurchase Intention. Furthermore, the Seeking variety variable has a regression coefficient value of $-2,346$ with a significant value of $0.103>0.05$, thus the Seeking variety has no significant effect on Repurchase Intention.

Meanwhile, the regression coefficient value for the moderating variable Seeking Variety was -0.537 with a significance value of $0.016<0.05$. So it can be concluded that the Seeking variety can moderate the influence of Customer Experience on Repurchase Intention in a negative direction. Each increase of one (1) unit of moderating variables (variety seeking) will lower the unit -0537 Repurchase Intention

\section{The coefficient of determination test ( $R 2)$}

Determination (R2) is used to see how much the contribution or contribution of Variety Seeking moderates the effect of Customer Experience on Repurchase Intention. shown in the table below:

\begin{tabular}{|l|l|r|l|l|}
\hline Model & $R$ & R Square & $\begin{array}{l}\text { Adjusted R } \\
\text { Square }\end{array}$ & $\begin{array}{l}\text { Std. Error } \\
\text { ofthe } \\
\text { Estimate }\end{array}$ \\
\hline 1 & $.295^{\mathrm{a}}$ & .087 & .077 & 5.25385 \\
\hline
\end{tabular}

It is also known that the R Square value is 0.087 or $8.7 \%$. This means that the contribution of Variety Seeking moderates the effect of Customer Experience on Repurchase Intention is $8.7 \%$, while the remaining $91.3 \%$ is influenced by other variables not examined in this study. 


\section{DISCUSSION}

After analyzing each data from the questionnaire, it is continued by testing the hypothesis. Based on the analysis, the research conclusions can be made as follows:

The Influence of Customer Experience on Repurchase Intention at 4-star Hotels in Padang City. From the linear regression analysis, it can be seen that the independent variable Customer Experience has a significant effect on the dependent variable Repurchase Intention. This can be proven from the calculated $F$ value of 13,460 with a significance value of 0.00 . Because the significant value is much smaller than 0.05 , with a regression coefficient value of 0.125 and an influential contribution value of $4.5 \%$, Customer Experience can be used to predict Repurchase Intention. Or it can be said that a positive change in Customer Experience has a positive effect on Repurchase Intention.

The good experiences that consumers get after staying overnight will encourage consumers to come back to the hotel (Cynthia Asrivionny Adytia and Yeni Yuniawati, 2015). Consumer behavior after using a product or service is directly proportional to the experience gained when consuming that product or service (Li et al., 2019) When consumers are satisfied with a product or service, consumers will recommend it to other people or buy back the product or service.

Based on the results of data processing, the regression coefficient value of Variety Seeking moderation is obtained. From the moderation regression analysis, it can be seen that the Seeking variety can moderate the influence of Customer Experience on Repurchase Intention. This can be proven from the calculated $\mathrm{F}$ value of 8,965 with a significance value of 0.00 less than 0.05 . From the test results moderated regression gets a coefficient of $-0,537$ with a significant value of 0.00 , and a contribution of influence of $8.7 \%$. So thus variety-seeking can moderate the influence of customers' experience towards repurchase intention in a negative direction, meaning that if there is an increase in the variety-seeking variable, it will be able to reduce consumer interest in staying back at the hotel.

The desire of consumers to look for product variations is not only due to dissatisfaction but also because boredom makes consumers buy products or services with different brands (Peter, 2013) The good experience that consumers get while staying is not necessarily able to make these consumers stay. Returning, the desire to look for variations will make consumers see other alternatives of similar products or services.

The need or desire to seek variety is a form of consumer desire to try new things that are rarely or never consumed (Schiffman, L.G., \& Kanuk, 2010). The behaviors to look for variations from consumers are 1 . The need for variation Consumers are already bored with the same product offered by a company, so the need for variation or something new is desired by consumers. 2. There is no innovation choice. Companies need to prepare regular innovations in their products to keep consumers in choosing the atmosphere and the variety of products offered by the company. 3. Perceived differences between brands Companies need to show good product quality and friendly service in maintaining competition between companies (Mowen, 2012). Seeking diversity (variety seeking) refers to the tendency of consumers to spontaneously seek to buy new brands of similar products even though they have expressed satisfaction with the old brand)

\section{CONCLUSION}

Based on data analysis of the research results, and the discussion that has been carried out in the previous section, it can be concluded that the research results are as follows: The effect of customer experiences on repurchase intention. From the results of linear regression analysis, it can be seen that the independent variable Customer Experience has a significant effect on the dependent variable Repurchase Intention. This can be proven from the calculated $F$ value of 13,460 with a significance value of 0.00 . The $\mathrm{R}$-value of 0.213 indicates that the correlation or relationship between the dependent variable and the independent variable has a strong enough relationship. From the table above, it is also known that the value of $\mathrm{R}$ Square to see the contribution of the influence of Customer Experience on Repurchase Intention is 0.045 . This means that the contribution of the influence of the independent variable on the dependent variable is $4.5 \%$, while the remaining $95.5 \%$ is influenced by other variables not examined in this study. Variety seeking moderates the relationship between customer experience and repurchase intention.

From the results of the moderation regression analysis, it can be seen that Seeking variety can moderate the effect of Customer Experience on Repurchase Intention. This can be proven from the calculated $F$ value of 8.9 with a significance value of 0.00 less than 0.05 . The regression coefficient of the Seeking Variety variable is -0.537 . 


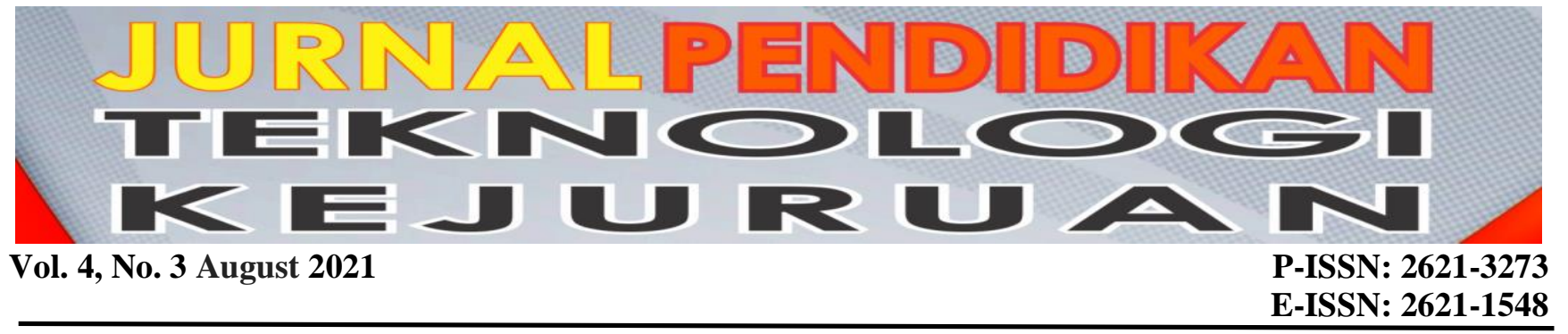

Based on the results of data processing, a significance value of $0.016<0.05$ was obtained. So it can be concluded that the Seeking variety can moderate the influence of Customer Experience on Repurchase Intention in a negative direction. Every increase of one (1) moderating variable unit (variety seeking) will decrease -0.537 Repurchase Intention units and the R Square value is known to be 0.087 or $8.7 \%$. This means that the contribution of Variety Seeking moderates the influence of Customer Experience on Repurchase Intention by $8.7 \%$, while the remaining $91.3 \%$ is influenced by other variables not examined in this study.

\section{REFERENCES}

Alnawas, I., \& Hemsley-Brown, J. (2019). Examining the key dimensions of customer experience quality in the hotel industry. Journal of Hospitality Marketing \& Management,28(7),833-861. https://doi.org/ 10.1080/19368623.2019.1568339

Bianca, I. (2011). faktor - faktor yang mempengaruhi minat menginap ulang (Studi Lor In Bussiness Hotels Resorts \& Spa, Solo). Jurnal Undip.

Cynthia Asrivionny Adytia and Yeni Yuniawati. (2015). Pengaruh Customer Experience Terhadap Revisit Intention di The Trans Luxury Hotel Bandung, Vol.V No.1. Tourism And Hospitality Essentials (The) Journal, 5(1), 857.

Hendra, N. (2019). "Tumbuhkan Investasi, Kawasan Pusat Kota Padang Siap Dibangun Hotel”. Cendana News Padang.

Hicks et al. (2005). Delighted Consumers Buy Again. Journal of Consumer Satisfaction, Dissatisfaction, and Complaining Behaviour.

Jorge Teixeira, Lia Patrício, Nuno J. Nunes, Leonel Nóbrega, Raymond P. Fisk, L. C. (2012). Customer Experience Modelling: from Customer Experience to Service Design. JournalofServiceManagement,23(3), 362-376.
Kandampully, J., Zhang, T., \& Jaakkola, E. (2018). Customer experience management in hospitality. International Journal of Contemporary Hospitality Management, 30(1), 21-56. https://doi.org/10.1108/IJCHM-102015-0549

Klaus, Ph. and Maklan, S. (2011). Bridging the gap for destination extreme sports a model of sports tourism customer experience. Journal of Marketing Management, 27, 1341-1365.

Kotler, Philip \& Keller, L. K. 2009. (n.d.). manajemen pemasaran. Erlangga.

Li, J., Hudson, S., \& So, K. K. F. (2019). Exploring the customer experience with Airbnb. International Journal of Culture, Tourism and Hospitality Research, 13(4), 410-429. https://doi.org/10.1108/IJCTHR-10-20180148

Mowen, j. and M. (2012). Perilaku konsumen. Erlangga.

Peter, J. P. and J. C. O. (2013). Perilaku Konsumen dan Strategi Pemasaran. Erlangga.

Riyon, F. (2019). FPM Ditutup, Wagub: Kunjungan Wisman ke Sumbar Meningkat di Tahun 2019. Dalam. https://ayokesumbar.com/13221-2/

Sang, H., Xue, F., \& Zhao, J. (2018). What Happens When Satisfied Customers Need Variety? Effects Of Purchase Decision Involvement and Product Category on Chinese Consumers' Brand-Switching Behavior. Journal of International Consumer Marketing, 30(3), 148-157. https://doi.org/10.1080/08961530. 2018.1423662

Schiffman, L.G., \& Kanuk, L. . (2010). Consumer Behaviour. Pearson Prentice Hall.

Sharma, Piyush, Bharadhwaj Sivakumaran, R. M. (2009). Impulse Buying and Variety Seeking: A Trait-Correlates Perspective. Journal of Business Research, JBR-06773, 8. 